\title{
Temporalizing Childhood: A Conversation with Erica Burman, Stephanie Olsen, Spyros Spyrou, and Hanne Warming
}

\author{
Zsuzsa Millei
}

Zsuzsa Millei is a professor of early childhood education at Tampere University, Finland. Her research addresses child politics by exploring how politics (power, government, nationalism, and ideology) intertwine with childhood and children's everyday life in child institutions and, more recently, reconfigured within the Anthropocene. Her comparative studies of nationalism and explorations of childhood memories of (post)socialist societies use postqualitative and artistic methods to expose complex matrices of power and seek to decolonize the research imagination and knowledge production. Her edited special issue on children and nationalism has recently been published in the journal Children's Geographies. Her coedited book Childhood and Schooling in (Post)Socialist Societies: Memories of Everyday Life (Palgrave Macmillan) and other articles and artistic explorations related to the Re-connect / Re-collect: Crossing the Divides through Memories of Cold War Childhoods project can be found on the website www.coldwarchildhoods.org .Email: zsuzsa.millei@tuni.fi

Erica Burman is a professor of education at the University of Manchester, an associate fellow of the British Psychological Society, and a United Kingdom Council of Psychotherapists registered group analyst (and full member of the Institute of Group Analysis). She trained as a developmental psychologist and is well known as a critical developmental psychologist and methodologist specializing in innovative and activist qualitative research.

Stephanie Olsen, PhD, FRHistS, is an historian of childhood and youth, education, and experiences/emotions and a senior researcher at the Academy of Finland Centre of Excellence in the History of Experiences (Tampere University). She is the author/co-author of two monographs, Juvenile Nation: Youth, Emotions and the Making of the Modern British Citizen (Bloomsbury, 2014) and Learning How to Feel: Children's Literature and the History of Emotional Socialization, c. 1870-1970 (Oxford University Press, 2014), and the editor of the collection Childhood, Youth and Emotions in Modern History: National, Colonial and Global Perspectives (Palgrave, 2015). She is the general co-editor of the forthcoming six-volume Cultural History of Youth (Bloomsbury) and the four-volume Children, Childhood and Youth in the Long Nineteenth Century: A Global Primary Source Collection (Routledge). She coedits the journal History of Education.

Spyros Spyrou is professor of anthropology at European University Cyprus. His work is mainly located in the interdisciplinary field of childhood studies where he has worked on questions related to children's political lives and identities (especially in relation to nationalism, migration, and borders) as well as issues related to poverty, social exclusion, and marginalization. He is currently engaged in research on youth participation in climate action. Spyros is the author of Disclosing Childhoods: Research and Knowledge Production for a Critical Childhood Studies (Palgrave Macmillan, 2018) and coeditor of Reimagining Childhood Studies (Bloomsbury, 2019) and Children and Borders (Palgrave Macmillan, 2014). He is also an editor of the journal Childhood (SAGE) and an editor of the book series Studies in Childhood and Youth (Palgrave).

Hanne Warming is a professor of sociology and childhood at Roskilde University in Denmark. Her research fields of expertise include childhood and youth, social changes, and how theorizing and findings from childhood studies can inform broader societal issues and change processes (ChildPrism research). Hanne is recorded in the European Expert Database of Outstanding Female Academics, "Academianet," and serves as a member of the advisory board for the Childism Institute, Rutgers Camden. She is the author of "Childhood Prism Research: An Approach for Enabling Unique Childhood Studies Contributions Within the Wider Scholarly Field" (Children's Geographies, 2020), co-author of "Future Workshops as a Means to Democratic, Inclusive, and Empowering Research with Children, Young People, and Others" (Qualitative Research, 2020) and Power and Reflexivity: Positions and Positioning in Involving Research with Young People (Palgrave, 2021), and coeditor of Lived Citizenship on the Edge of Society: Rights, Belonging, Intimate Life, and Spatiality (Palgrave, 2017).

This paper is a summary of the keynote panel conversation that took place as part of the "Childhood and Time" conference, May 10-12, 2021. The speakers respond to the question of how they place childhood in time relations, giving examples from their own research and outlining an agenda for considering time in childhood studies.

Key words: time; childhood studies; Anthropocene; history of childhood; climate action 
The felt effects of the escalating climate catastrophe give evidence for geologists' claim that the earth is now in a new geological epoch, the Anthropocene. Human activity significantly affecting the climate and ecosystems makes us realize the inseparability of Earth time (geologic time divided into eons, eras, periods, epochs, and ages) and humancentric time (length of human life). Another major event, the global COVID-19 pandemic, is altering the personal sensation of time by interrupting usual routines and the rhythms of life, intensifying the sensation of its circularity (days becoming the same) and even stopping time. These life-altering changes-of Earth ecosystems and personal lives-necessitate destabilizing and examining pervasive conceptions of time constructing, historicizing, structuring, materializing, controlling, governing, and sequencing childhood and children's everyday lives (for earlier explorations on time and childhood, see Tesar et al's 2016 edited special issue; also Murris \& Kohan, 2020). In this conversation, I place childhood in time relations with four invited panellists from the "Childhood and Time" conference in Tampere held in May 2021: Erica Burman, Stephanie Olsen, Spyros Spyrou, and Hanne Warming.

In 1986, Judith Ennew raised the importance of facilitating a wider and more critical thinking about time and childhood, suggesting that "time may be crucial to the study of childhood ... as a social institution and about the lives of children themselves" (p. 21). Allison James and Alan Prout (1997) also pointed to the centrality of time in concepts of childhood by outlining that time constructs child/hood in at least two ways: time of childhood, referring to the periodization of the life course; and time in childhood, according to which "time is used effectively to produce, control and order the everyday lives of children" (pp. 227-228). Time, as continuity and change, is also crucial to understandings of the social spaces of childhood in different eras and societies, including conceptions and ideals of childhood and children as a social category. In modern societies, time is "measured and contained, it became expressed in minutes, days, weeks, years and in categories such as generations" (Jenks, 1996, p. 105), creating spaces for and materializing child/hood. Time marks out personal ability and development, responsibility, and expectations; it connects unconnected events through the notion of linear progress. Colonial expansion and capitalism intensified the spread and power of this modern construction of time, demanding that the peripheries (the Global South and later the former Second World) catch up and regulate their societies and childhoods according to it (Cannella \& Viruru, 2004; Silova et al., 2017). Children thus were relegated to the "right" place at the "right" time, confirming the position of school and other key normative institutions as organizing children and childhood in dominating societies.

From the outset, a key agenda of childhood studies was a deliberate shift away from the futurity of childhood, as captured in the notion of "becoming" imposing linear temporality and progression over children's lives. Scholars wished to trouble child development theories that mapped children's competencies toward reaching predetermined stages in their progression to adulthood and future participation in society. The task was to recognize children as active participants and "beings" in the present of social life (James \& Prout, 1997). This shift mapped the field against developmental trajectories, including individual, societal, political, and economic concerns related to adult agendas. The focus on children's everyday life also opened spaces for engaging with how time operates in children's familial, institutional, public, and natural environments. This included how clock time and calendar time organize shared life-forming rhythms and temporal patterns such as schedules, routines, circularity, or celebrations (PaciniKetchabaw \& Kummen, 2016), since habitual practices are time-space routines producing a feeling of belonging within the rhythm of life in place.

Amid current claims of accelerating societies characterized by time-space compression, nevertheless societal times and children's times and rhythms may differ. Children may feel hurried, "out of time," or in need of carving some space and time for themselves. While children's time is often seen as not "real time" by adults, children may also experience time differently, when the world can happen (Rautio, 2013). As Wyness (2006) notes, the notion of 
childhood as a period of play and “irresponsibility' cannot be equated with the time adult time is measured” (p. 108).

Zsuzsa: How do you think "adult time" and "child time" and the changing rhythms and paces of time shape how children lead their lives today, particularly within the current anxiety over the future considering the accelerating and life-threatening effects of climate change and the COVID-19 pandemic?

Hanne: When I was a young child, I felt that an hour was a very long time. I could struggle to make time go by, for instance, waiting for my mum to pick me up from the half-day daycare. Today, on the contrary, I struggle not to miss time and to have enough time, and a year feels like a very short time. The older I become, the faster times pass by. This might be seen as a change related to age and life course, but it may also be related to socio-historical changes of pace of life as described by Hartmut Rosa-and if so, it probably characterizes children's experience of time, too-maybe they also struggle to have time enough. According to Rosa (2013), our lives are accelerated in three dimensions. The first is technological speed, the second is the speeding up of social change, which causes an experience of "contraction of the present." The third form of acceleration is the pace of life, that is, the experience that we must "run" faster to keep our place in the world. All three dimensions are also present in children's lives, maybe especially the last one. A central point in Rosa's theory is that these acceleration processes are not only driven by capitalism and worldwide competition-which they also are-but intervene in, and intersect with, subjective drivers of hope and fear. Hope in the sense of the aspiration to achieve a good life, and at the same time fear of (and efforts to prevent) falling behind. But what happens with these individual hopes and fears-the drivers of acceleration of pace of life-with today's apocalyptic turn, with the collapse of the future as appealing and promising?

Here, childhood studies could make an important contribution, since the discursive/material turn towards the apocalypse might prove more drastic in children's lives-just one example of the potentials of childhood prism research for contributions to the broader field of social sciences and humanities (see 2020 special issue of Children's Geographies edited by Warming). Exploration of children's (and our own childhoods') time experiences and struggles can be seen as a kaleidoscope of childhood (Millei et al., 2019) or, as I have conceptualized it, as a kind of prism, or even a diffractive microscope for studying ongoing social changes and struggles, not only relating to childhood but to broader societal issues as well (Warming, 2020).

Another time experience from my childhood is time as circular: days followed by nights followed by days and so on; the week as a circular movement through seven days; the year as a circular movement through seasons. Time as circular and immersion in the here and now have been associated with nature, precapitalist living, animals, children, and women, and as intruded upon by a white capitalist male linear and progressive temporality (Fuchs 2018; Kristeva, 1981; Lewis, 2014). Still, both circular and linear time experiences characterize children's-and adults'-lived time. In my childhood, I for instance experienced the life course as a linear movement. I deeply wanted to escape-not to escape death-no, what I feared was adulthood, which at that time appeared to me as loaded with burdensome responsibility, troubles, and work-no fun. Just like Pippi Longstocking in the book authored by Astrid Lindgren, I wished never to become an adult, and if I had been given the possibility-as offered by Pippi to her two friends Tommy and Annika, I would have taken the "I will never grow up" pill. Today, the future invades the present and children are mobilized to take a stance and participate in making the future.

The "invasion" of the future in the present is not a new idea. In 1989, Nicolas Rose pointed out how childhood, due to this idea, has become "the most intensively governed sector of personal existence" (p. 121). Indeed, children have become key objects of what he terms "community governance"-a form of governance that is directed towards a certain group due to its identified features of "strengths, potentials, cultures and pathologies" (p.331. 
Several presentations during this conference have critically addressed and analyzed this intensified governance of childhood, especially early childhood, as imposing linear temporality and progression. In our time of global capitalism, children more than any other population are being addressed by such governance strategies driven both by ideas about which kind of citizens will enable the nation-state to do well in a global capitalist society and by an image of childhood as the cradle of tomorrow's values and morals, for example, related to issues of climate change and citizens responsible for their own health. An additional source of the invasion of the present by the future in children's lives derives from the fact that children have moved to the forefront of parents' hopes, ambivalent desires, and struggles for independence, love and happiness, as pointed to by Ulrich Beck and Elisabeth Beck-Gernsheim back in 1995.

Whereas the invasion by the future has roots in the 1990s and even further back, something dramatic has happened-namely the appearance of a sense or feeling of apocalypse being imminent. I see this feeling as an accelerating game changer. Increasingly, the future appears as a discursive/material matter of a thread and a failed promise. Back in the 1950s, 60s, and 70s in the Western world, and despite the Cold War threats of nuclear war, children were told-and, I think, also believed and experienced-that the older generations by the sweat of their brow had prepared the way for a bright future with infinite possibilities. Today, children face a very different discursive/material reality of climate change, pandemics, terrorism with weapons of mass destruction, and masses of people on the run-resulting in the feeling of apocalypse being imminent. Child climate activism can be seen as one expression of, and reaction to, this feeling. I suggest that this turn from hope and promises for the future towards apocalypse is one of the most drastic material/discursive changes of childhood and human life, and that it may have a serious impact on the generational relationship too. Much research is and has been done regarding the dynamics and scopes of the apocalypse drivers. Less-if any-explores the consequences of the collapse of the future in terms of the apocalypse and the accompanying material/discursive changes in child/hood, human life, and generational relationships.

Zsuzsa: Hanne, you have highlighted the negative effects that the future orientation and expectations and the invasion of the future into the present bring, and especially how they shape children's lives and their material and social relations. You also hinted at how anxieties around our human-generated ecological epoch, epidemics, and political violence worldwide mobilize children to engage with the future in more political terms. In earlier historical periods, for example in the socialist states, children were the icons of the desired societal change and the drivers of change by growing up to be the next generation, the ideal "socialist human" (Silova et al., 2017). As you explained, children are governed to become productive citizens to reach their nations' economic and nation-building goals (Burman, 2021). It seems today more and more young people refuse the form of citizenship assigned to them and are taking the future into their own hands and demanding a stake in it. Spyros, could you talk more about future, childhood, and politics in relation to your research?

Spyros: I could relate my answer to the notion of the "future-in-child." Holland and colleagues (1998) have used the notion of "history-in-person" to refer to "the sediment from past experiences upon which one improvises, using the cultural resources available, in response to the subject positions afforded one in the present" (p. 18). Adapting this conceptual understanding to the child, we might find it fruitful to think about history-in-child but also, additionally, about future-in-child as the amalgamation of futural orientations and imaginaries which enable the child to act upon the future from within the subject positions they occupy in the present. My personal concern with the future in childhood studies stems from what I see as a reluctance on the part of the field to fully explore the multiple temporalities of children and childhood and to step outside its narrowly conceived fixation with the present. Veronica Pacini-Ketchabaw's keynote speech at the conference and her suggestion that we should "multiply our understandings of time" and think beyond linear time while also "not leaving the present to neoliberal and 
colonial futures" is a good starting point for reflection and certainly a very important provocation for the field.

Of course, we do not have anything else but the present to work with-neither the past nor the future is directly accessible. Nevertheless, we need to bring these temporalities into our accounts of contemporary children and childhood. By doing so, I think we are opening the field to more critical engagements with time, which is after all a key dimension of life. In a Childhood editorial from last year (Spyrou, 2020), I suggested that we can think of children as future-makers (and take them seriously as such) considering their increasingly visible role in climate action around the world. By that, of course, I did not mean that we should equate children with the future or that the future belongs to children (which would be a kind of naive, simplistic, and reductionist understanding) but rather acknowledge that we need to recognize children as legitimate participants in struggles to shape the future and to potentially craft alternative futures. If children are oriented in their everyday lives by the future, by what is to come and not just by what is, then perhaps we need to "retemporalize" the field, at least in the sense of allowing it to engage more explicitly with children's futural orientations. In that case, we need to develop better ways of exploring how their practices, their values and desires, their aspirations, their fears and hopes in the present are shaped and impacted by their orientations to the future.

My colleagues Eleni Theodorou and Georgina Christou and I are currently working together on an ethnographic study of young climate activists in Cyprus (funded by the A. G. Leventis Foundation and the Hellenic Observatory at the London School of Economics and Political Science). My thinking on some of these issues has been shaped by the kinds of questions we are engaged with in this study. One of the issues we are trying to explore, for instance, is "What kinds of children are constituted as a result of the climate crisis and children's participation in the climate movement as activists?" In other words, we are trying to understand what the future does to these children in their everyday lives in the present and how they orient their thinking, their actions, and their activism based on their assessments of the future. Relatedly, we are also trying to understand what kinds of future worlds these children imagine, try to forestall, or make possible. It is interesting to note here (at least based on our own study's findings) that young climate activists see themselves in many ways as the future, because they feel that their generation will be affected disproportionately by climate change, and they need to do something about it, but they also recognize the need for intergenerational solidarity in the fight against climate change.

So, in some ways, through our engagement with the future in childhood studies, we are offered an opportunity as a field to move beyond our critiques of what is inadequate, problematic, or wrong with the world and with contemporary childhoods and towards more affirmative explorations of what kinds of worlds might be possible. This could take childhood studies to the next step of critical inquiry and allow scholars to collaborate with children in coproducing and disclosing knowledge about alternative futures (Spyrou, 2020).

To take up this challenge we might have to think more generatively as a field about new concepts and ideas which might offer us different and more productive ways of thinking about the relationship of childhood and time, and of childhood and the future. Fear, anxiety, uncertainty, and urgency might be some concepts which are useful, especially when we think about the crises which confront children today. Hope (and especially collective hope) might be another key concept here which might offer us explanatory power for understanding children's political participation and their engagement with global issues at large. In our work with the young climate activists I mentioned earlier, collective hope emerged as a key orientation towards the future and as a primary means through which the young activists managed to keep going considering the climate crisis. They turn to hope to anchor their activism in the present and to create a sense of possibility through their collective participation in a social movement, which in turn reinforces their willingness to engage in activism. Collective hope offers these young people a way out of the despair they feel considering the climate crisis and to imagine and work towards more 
desirable and sustainable futures.

Zsuzsa: Hanne emphasized the possibilities and importance of studying society through children's "beings" enfolded within societal, political, and ecological changes. Spyros called into consideration how children's own futural orientations and imaginaries-the future-in-child-materializes in the present lives of children as they collaboratively and intergenerationally make futures. For me in Hanne's and Spyros' accounts, the emotional climates and affective regimes that envelop children's lives also stood out. Fear, anxiety, hope, uncertainty, and urgency are all feelings associated with the ensuing apocalypse and ongoing epidemics and are also attached to an emerging activist solidarity. These feelings lead me to ask Stephanie, who is a historian of emotions, how does the past and present structures of feelings place childhood-being and becoming-in time relations?

Stephanie: For an historian of childhood, historical time raises the question, how was childhood in the past different from that in our own worlds now? From a big-picture disciplinary perspective, this question provokes fundamental questions about periodization and whether conventional periods in history even make sense when our focus is on children. New child-centered periodizations are sometimes necessary to tell the stories historians want to tell and to do justice to child voices (or absences) in the archives (for more on this issue, see Alexander, 2012). From an historian's point of view, the concept of time is useful for understanding how experience was parcelled out in childhood and in children's lives in the past-the everyday; play time; work time; school time; family time; peer time - and how this breakdown of the day, month, year changed for children over time. It also raises questions about the relatability of the past to the present: the historicity of childhood and children. Everything about children's contexts is contingent and should therefore be viewed with a critical eye through a contemporary lens, even things that might appear to be self-evident or natural, according to the evidence of our own experience of childhood. I want to return later to the problematic idea that we have indeed all had a "childhood."

Time also brings to my mind thoughts about age cycles. Why has childhood been so extensively historicized but adulthood has not? After all, aren't humans at every stage in the life cycle always in a state of becoming as well as being? The changing conception of childhood itself as a distinct part (or not) of the lifecycle has been a major topic for historians. Futurity - the future as imagined time for children as potential adults, and as future members of their nations, societies, communities - is an important feature in my work. Children as beings or becomings, as humans in their own right or as future adults, are at the heart of the rise of the history of childhood, of trying to find children's "voices."

In a recent lively debate, Sarah Maza (who, by the way, is not an historian of childhood herself) was rather hard on our field. She writes that "THE HISTORY OF CHILDREN AND CHILDHOOD is always on the rise and yet not quite risen" (Maza, 2020, p. 1261, original emphasis). But she does suggest that "a productive shift has been emerging from writing the history of children to writing history through children" (p. 1263). Many historians of childhood would disagree that this is the way the field should go in order finally to "have risen," but it is at the core of a basic question about childhood versus children, and children as beings versus becomings.

Zsuzsa: Let me interrupt you, as I feel there is an important connection that we need to point out. You describe child-centered periodizing and writing history "through" children's experiences. This idea for me runs parallel to Hanne's agenda of studying society through children's experiences and resonates well with Nick Lee's (2001) notion of "immature" sociological theorizing, with which he calls on social theorists to write theory with children also in mind. I think temporalizing social and political theory and history with childhood could bring important challenges and highlight the limits and pitfalls of contemporary theorizing within these disciplines that dominantly focus on explaining adult experiences (see, for example, Beier, 2020). 
Stephanie: Let me continue with Karl Hanson's (2017) addition to being and becoming, of the "been" of the child. Hanson explains that,

compared to the binary being versus becoming ... the triolectical conceptualization composed of "been," "being" and "becoming" offers a more productive lens for the study of children and childhood, as it includes more complex relationships between children's past, present and future. (p. 282)

As I hinted at earlier, all humans are in a continual dynamic process of all three of these processes, and therefore understandings of the lifecycle should not be linear. Analytically, I don't think there should be a dichotomy between becoming and being and between ideals of, and interventions in, childhood (history of childhood) and the experiences of children (history of children), since children themselves have been active participants in efforts of becoming. People often face the logics and experiences of their own present as "natural," given, and obvious, and the experiences of child actors get built into this state of givenness. Historians' interventions should be a reminder to the larger field of childhood studies that such feelings of givenness are always constructed and situated. To reveal them as such in the past, often in greatly unfamiliar forms, is both a prompt and a guide to examine otherwise invisible assumptions in the present. From the perspective of past contexts, our present-a given, from our perspective-was the future: unknown and inscrutable. My point here is that children actively engaged themselves in becoming, in participating in adult efforts to educate and enculturate, as well as in child-directed efforts. They prepared for these "unknown and inscrutable" futures in situated ways, building on the "been" of children in its multiplicity of forms.

We can describe empirically and in detail how childhood and children's lives were historically contingent, and also demonstrate how childhood's changing forms and requirements are always political. Historical studies serve as reminders of the situated construction of childhood in the present, of the contingent societal processes that shape children's unfolding lives. Historians produce knowledge about childhood that should be leveraged against current understandings of the present. Let me give you a brief example related to this idea of becoming, of futurity, of building on the been, from my own period of study as an historian of education. It is drawn from the context of $19^{\text {th }}$-century Britain as a colonial power and the extreme of this imperial logic of childhood in a colonial context: Canadian residential schools for Indigenous children.

Understandings of children as innocent and malleable became increasingly dominant in the $19^{\text {th }}$ century, yet not all children were perceived to have these qualities equally (Olsen, 2014). The judgment of colonial policy makers and the effect of colonial practices in general created a hierarchy of childhood embedded within complex schemes of class, race, gender, sexuality, and geography that determined and naturalized lines of inclusion and exclusion within discourses of docility, plasticity, and potential.

Canadian residential schools operated in the $19^{\text {th }}$ and $20^{\text {th }}$ centuries, the last one closing in 1996 . The strengthening notion of childhood innocence and malleability was here poisoned by contemporary racial theory that dehumanized Indigenous children, providing potent reasons to make Indigenous children a target of these institutions. The stated goal of these "schools" was to "civilize" Indigenous children, to remove them from the "corrupting" influences of their parents, families, and communities, and to forge new Canadian citizens out of them. They were sites of emotional, physical, and sexual abuse and cultural belittling and denial (children were given a uniform and a number) in a concerted effort to strip away the individual. These practices have been described as "cultural genocide" (e.g., Miller, 2006, p. 9). In 2015 the Canadian government concluded a Truth and Reconciliation Commission inquiry during which many survivors gave testimony and cogently explained how this fusion of ideas of childhood, racism and nationalism/imperialism impacted them as individual children through their schooling. 
Though the examples from Canadian residential schools are disturbing, they are hardly unique (Gordon, 2008; Swain \& Hillel, 2010; Vallgårda, 2014). The legacy of the residential school system remains in the physical and emotional health and welfare of Indigenous people. Its monstrous destructiveness is still being uncovered, as in the recent discovery, for example, of the remains of 215 children in unmarked graves at the site of the former Kamloops Indian Residential School (Dickson \& Watson, 2021). This system is not a blip in the Canadian national story but rather a foundational element in the British imperial project and the creation of Canada as a nation. It is the fusing of late-19 $9^{\text {th }}$-century ideas about childhood and education with contemporary notions of racial hierarchy, nationalism and imperialism, and a "civilizing vision" of the futurity of the child. For those children, nothing was given. These "schools" aimed to re-form Indigenous children into Canadian subjects worthy of a "childhood" and a future. In so doing, their "been" — that is, their Indigeneity and ties to their cultures, communities, and familieswas annihilated.

Zsuzsa: Your thoughts add a generative complexity to temporalizing childhood. Besides the different notions of time we have discussed so far, such as societally constructed futures, future-in-child, and past-in-child, you added the "been" as necessary for investigations of childhood and children's lives in the present. You also brought a very sobering example of the importance of historical method and theory for our present investigations in childhood studies. It is important for childhood researchers to keep in mind and keep being troubled by how the reasons and logics that were taken for granted during a historical period made possible the continuation of such practices in residential schools for a long time. Childhood researchers can apply a similar kind of awareness to the motives and explanations that operate in our present to destabilize, explore, and contest the givenness of current processes and politics shaping childhood and children's lives. With what reasonings and motives is the climatic regime (discourses and power relations) being explained, and how do those shape child/hood and the politics it promulgates for children, for their present and future, and by children?

Spyros: I think that the conference theme captured a reflexive moment in the history of childhood studies when we need to think more creatively and productively about the intersection of childhood and time in ways that are theoretically more nuanced and allow us to avoid the temptation of simply adding a new element (time in this case) to childhood and considering that to be sufficient. How can childhood studies make time a constitutive element to its object of inquiry - the child? Several presentations at the conference pushed us to think more broadly about childhood's temporalities in ways that go against dominant understandings of time. For instance, there were many wonderful presentations on multispecies enquiries and more-than-human childhoods which moved us to go beyond anthropocentric notions of time in childhood and to think otherwise. This kind of fruitful engagement is what allows us, I think, to sustain our claim to be reflexive as a field.

Zsuzsa: Many presentations highlighted the impossibility to separate human-centered and Earth time, and human and earth history, and how they are entangled in worlding the future, adding other important considerations to temporalizing childhood.

Erica: I think also that there needs to be more attention to reflexive issues but also a different kind in terms of how we are positioned by, and in relation to, temporalities surrounding children and childhood.

Being reflexive about researching children and childhood means understanding, or at least acknowledging, how the memory of one's own childhood and personal history enters into one's dealings with those positioned as generationally after us. This includes understanding how our commitments to notions of futurity, of progress, or maturity, or "growing up" are also inflected by this history, as well as performed in relation to current contexts and audiences. 
My interest in psychoanalysis originates in my interest in the politics of developmental psychology and the ways conceptions of time inform ideas about childhood and development. It goes back a long way. As a second-year undergraduate (studying developmental psychology and cognitive studies), I encountered a paper on childhood and time by Bergler and Róheim (1946), which contained the provocative phrase 'The calendar is an ultimate materialization of separation anxiety" (p. 206). What, I pondered, did the emotional dynamics of caregiverchild separation have to do with cultural artefacts, such as calendars and timetables, that structure the pace and rhythm of social relations (including children's lives)? I dismissed it; it irritated me, but then it kept returning to me. It was the slow process of exploring and unravelling what this cryptic phrase might mean that in some way inspired my doctoral research (on children's conceptions of age and time, Burman, 1990) and led me to critiques of development, postdevelopment, and postcolonial studies. It took me to deconstructing development (Burman, 2017) and then exploring developments (in the plural; Burman 2021) so attending to multiple modernities and their limits (Bhambra, 2007) and then trying to attend to their specificities (via my notion of child as method [Burman, 2019]).

Fanon also subscribed to some common assumptions. In particular, he both opens and closes his first book, Black Skin White Masks (1952/1967), with an epithet he attributes to Nietzsche: "The tragedy of the man is that he was once a child." Leaving aside the "man" question for just a moment, it is worth asking what this rather cryptic phrase conveys, and what work it does in framing what has since become one of the most crucial accounts of subjectivity, subjectification, and the psychic impacts of oppressive social conditions and practices (i.e., racialization in the context of colonialism).

Clearly this phrase indicates Fanon's subscription to a psychoanalytic framework, one that attends both to the impact of early experience in shaping later understanding-history-in-child as Spyros alluded to-and also how the memory of childhood is selected (or versions of those memories) according to current psychic preoccupations, that is, as retrospectively mobilized and organized for present purposes.

I suggest researchers need to attend to both these aspects in the generation and analysis of accounts of childhood. Holding onto both the psychological and (what now is called the) performative aspects of narratives of childhood (which are sometimes also narrated by children too) is tricky, both emotionally and analytically. But it is at this intersection, that is, where the subject of the narration and its enunciator meet, that the core political and analytical work of exploring the stakes of and in childhood occur.

I recently discovered some discussion about this evocative phrase that Fanon uses: "The tragedy of the man is that he was once a child." It seems that this derives not from Nietzsche but from Simone de Beauvoir (Adkins, 2013). Now it is well known that Fanon hugely admired and was very influenced by Jean-Paul Sartre, and that shortly before he drafted his final book Wretched of the Earth (the book he wrote in the final weeks of his short life) he spent an intense few days with both Sartre and Beauvoir.

To (over)simplify those discussions in the interests of space, this phrase is understood to refer to the legacies of the child's fears that remain present or are evoked in the adult. These legacies comprise each of our "tragedies," in the sense that they continue to affect us and distort or impair our (political) action. Moreover, and going beyond Hanson's (2017) notion of childhood as been, the recollection of "having been a child" can become retrospectively and nostalgically reconfigured as a period of life that came before one's awareness of current constraints and limitations. In philosopher Lewis Gordon's (2015) account, Beauvoir explored this notion in terms of the specific modes of embodiment and identities "and the specific longing human beings may have for times before such ways of being were realised" (p. 31). For Beauvoir this was about gender. Fanon, of course, took this up in terms of racialization. 
Fanon's existential, radical humanist commitments saw maturity as a matter of facing up to one's political and personal responsibilities This "maturity" (the dominant developmentalist trope that, as we know, recapitulates masculinist and linear as well as colonial nuances of "mastery") was something that Fanon was clearly very invested in. As Gordon (2015) discusses, this investment was rooted in his own biography, growing up in Martinique where French rule both overlooked and displaced African matrilineal sources of power and, even as it offered men patriarchal authority, it also undermined and denied this by the racialized inferiorization structured into colonial relations.

Like Fanon, we all have our own specific histories, whose continuous resonances cannot but be at play in our work, as our lives. This is something, therefore, we have to work with, rather than overlook, and it is great to see, for example, papers engaging with these questions, such as in the postsocialist childhoods project (e.g., Millei et al., 2019).

Let me add one more link back to Fanon, Beauvoir, and this curious phrase. Its first mention by Fanon (1952) is qualified by the sentence that follows: "Nonetheless ... the neurotic's fate lies in his own hands" (p. 9) —which confirms Fanon's conviction that we can still overcome psychological obstacles. The last iteration is preceded by the sentence "At the beginning of his life a man is always clotted, he is drowned in contingency" (1967). Such an evocative but cryptic claim, which suggests that the child is perhaps not yet fully formed ("clotted"), as well as being vulnerable (to being drowned perhaps?), with its fate a contingent and not fixed matter. And it is succeeded by the assertion of the need for critical reflexivity for personal and political transformation: "It is through the effort to recapture the self and to scrutinize the self, it is through the lasting tension of their freedom that men will be able to create the ideal conditions of existence for a human world" (p. 165).

In more recent translations, the French word malheur is translated as misery rather than tragedy. This shift offers further psychoanalytic connections, recalling Freud's claim (elaborated in his Studies in Hysteria, co-authored with Breuer) that, rather than offering a cure, psychoanalysis turns hysterical misery into ordinary unhappiness. That is, distress-including the distress inherent in the human predicament, as well as that encountered through its injustices-becomes socialized, is shared, and becomes a joint, collective, or at least communicative condition. In this sense, as Fanon put it, sociogeny replaces ontogeny, including socially situated recollections and reconstructions of childhood. This collective sharing is the route towards political and social engagement and sociopolitical transformation, for children and also adults.

My key point here is not only that there are various kinds of "child" in Fanon, but also that childhood is not only the domain of trauma (either as the site of or, alternatively, as having installed the traumatic past). Rather, my argument here-for our discussions of time and childhood-is that the fact that we have all been children is a matter that has to be taken seriously as figuring within our childhood-related work. This matter may be historical and psychic, but it both was and is material. That is, in addition to having affected our lives in the past, these memories still matter insofar as they still animate our lives in ways we are not always aware of. Accounts of the ambiguous agency of the chronological child (i.e., child as a person defined by age) and generational child (i.e., children who come generationally after us), I suggest, need also to be read in relation to recalled and reexperienced childhood experiences that are activated by this memorial matrix and its complex associations, and that are irreducibly political as well as personal.

Zsuzsa: Originating in their own childhoods, researchers' personal fears and histories linger in their studies, gesturing forward, and compose another form of futurity that researchers need to attend to. Thanks for highlighting this important political and ethical aspect of research, Erica. Many thanks, Hanne, Spyros, and Stephanie as well for the gripping conversation. You have placed childhood and considerations accompanying childhood research 
into manifold space-time relations: Earth and human history, Earth and humanity's possible futures, the been of childhood, the past-in-child and future-in-child, and researchers' futures of the past. It seems to me that temporalizing childhood brings new energies, revitalizing and making more thorny childhood studies' initial agenda of focusing on children's present. The original agenda of childhood studies aimed to displace futurity vested in modern notions of development, both as future orientation and the governing effects of future. You brought back into our considerations other notions of future that matter in ethical, political, situated, and speculative ways. These add productive tensions and contestations to research in childhood studies and its engagement with time.

For me a couple of these tensions create troubling realizations and raise further questions. First, if future appears as a failure-humanity causing the apocalypse on Earth as Hanne described-how is it possible to orient towards it? This kind of futurity jeopardizes (at least at the scale of human experience) the inexorability of this futurity itself. In other words, there is a sense of lost or taken futures. In a way futurity destroys the possibility of future. This paradox diminishes hope, itself a "modernist imaginary (with its optimistic telos of universal knowledge and progress) and its romantic critical counterpart of re-enchantment and hope" (Chandler, 2019, p. 695). Hope is closely attached to futurity and future-making in modern societies. Modern generations following each other laid down future after future with a hope for progress. Each future was an alternative to what existed, and the old future was disposed of. In this way, layers of futures were laid upon each other and old futures and their hopes crumbled (Ingold, 2020). For example, and because the apocalyptic future Hanne pictured is somewhat like the future of the Cold War's nuclear catastrophe, socialist futures and hopes were quickly abandoned after the fall of the Berlin wall, and the new futures did not leave only the wall, institutions, economies, and hopes to crumble, they also made people's past disappear, setting them on an alternative trajectory and expectations towards consumer capitalist development (Silova et al., 2017). It seems today that these futures of the past have never arrived, and they might serve as cause for disappointments and gesture forward. In this sense, this kind of future-making is unsustainable as futures never stay and past futures remain, fuelling the present with affective remains (Ingold, 2020). At the same time, hope accompanying possible alternative futures is associated with human empowerment and redemption, with solving problems by intervening, adapting, and being resilient, which all are based on a belief in progress and human mastery and remain an "unchecked privilege of the moderns" (Chandler 2019, pp. 695-696). Hope engendering alternative possibilities is thus a flight from staying with the trouble of the reality of extinction (multispecies, including humans). Therefore, hope is a part of the problem (Latour, 2017). Could it be that those alternative possibilities that young generations currently create only but repeat "bestowing an epic agential power in 'man"' (Clarebook, 2015, p. 176, as cited in Chandler, 2019, p. 704), and the hope generated by these imaginaries only but reproduce modern futurity in a paradoxical way?

Second, futurity appearing in historical studies as the past's futures shaped children's beings and becomings in the past, and these "have beens" of childhood also contour the present, the beings of children and adults alike. Past futures tied to "civilizing" colonized populations, mixed with racializing practices, governed Indigenous children and adults' lives intensively in the past and continue to do so in the present. The recognition of the past's futures affords grounds for reconciliation and refusal, and for the recognition of unrealized or lost futures and lives as well that linger and contour the present. Other pasts' futures, for example the socialist ones, which elevated childhood to an iconic state of the revolution for a more economically and socially equal and just society, create nostalgia in the present and project towards the future as well. Thus, the recognition of pasts' futures and fears-both in past societies and researchers' personal lives-the traumas, losses, hopes, alternative possibilities, and "better lives" that were invested in childhood and socialized children and adults-provides important reflexive tasks for childhood research around futurity. At the same time, other kinds of reflexivity are also vital, such as to "engage for real in an apocalyptic discourse" and to think more seriously about the present when modernist hopes, progress, and reason have exhausted themselves (Latour, 2017, p. 194). For researchers, these kinds of reflexivity give a double task of 
asking "hard and provocative questions, disturbing complacency, troubling norms, and interrogating conventional truths. It involves interrupting the business-as-usual of everyday life and practice" (Taylor \& Pacini-Ketchabaw, 2015, p. 1), the givenness of the present, and questioning the givenness of the future as well. 


\section{References}

Adkins, A. V. (2013). Black/feminist futures: Reading Beauvoir in Black Skin, White Masks. South Atlantic Quarterly, 112(4), 697-723. https://doi.org/10.1215/00382876-2345243

Alexander, K. (2012). Can the Girl Guide speak? The perils and pleasures of looking for children's voices in archival research. Jeunesse: Young People, Texts, Cultures, 4(1). http://jeunessejournal.ca/index.php/yptc/article/view/154

Beck, U., \& Beck-Gernsheim, E. (1995). The normal chaos of love. Polity Press

Beier, M. (Ed.). (2020). Discovering childhood in international relations. Palgrave Macmillan.

Bergler, B., \& Róheim, G. (1946). Psychology of time perception. The Psychoanalytic Quarterly, 15(2), 190-206. https://doi.org/10.1080/ $\underline{21674086.1946 .11925639}$

Bhambra, G. K. (2007). Multiple modernities or global interconnections: Understanding the global post the colonial. In N. Karagiannis \& P. Wagner (Eds.), Varieties of world-making: Beyond globalization (pp. 59-73). Liverpool University Press.

Burman, E. (1990). Time, language and power in modern developmental psychology [Doctoral thesis, University of Manchester]. ProQuest Dissertations and Theses.

Burman, E. (2017). Deconstructing developmental psychology (3 $3^{\text {rd }}$ ed.). Routledge.

Burman, E. (2019). Fanon, education, action: Child as method. Routledge.

Burman, E. (2021). Developments: Child, image, nation ( $2^{\text {nd }}$ ed.). Routledge.

Cannella, G., \& Viruru, R. (2004). Childhood and postcolonization: Power, education, and contemporary practice. Routledge.

Chandler, D. (2019). The death of hope? Affirmation in the Anthropocene. Globalizations, 16(5), 695-706. https://doi.org/10.1080/1474 $\underline{7731.2018 .1534466}$

Dickson, C., \& Watson, B. (2021, May 27). Remains of 215 children found buried at former B.C. residential school, First Nation says. CBC News. $\quad$ https://www.cbc.ca/news/canada/british-columbia/tk-eml\%C3\%BAps-te-secw\%C3\%A9pemc-215-children-formerkamloops-indian-residential-school-1.6043778

Ennew, J. (1986). The sexual exploitation of children. Polity Press.

Fanon, F. (1952). Peau noire, masques blancs. Le Seuil.

Fanon, F. (1967). Black skin, white masks (C. L. Markmann, Trans.). Grove Press. (Original work published 1952).

Freud, S., \& Brauer, J. (1895/2004) Studies on hysteria (Studien über Hysterie). Penguin Classics.

Fuchs, T. (2018). The cyclical time of the body and its relation to linear time. Journal of Consciousness Studies 25, 47-65.

Gordon, L. (2008). The perils of innocence, or what's wrong with putting children first. The Journal of the History of Childhood and Youth, 1(3), 331-350. http://dx.doi.org/10.1353/hcy.0.0021

Gordon, L. R. (2015). What Fanon said: A philosophical introduction to his life and thought. Fordham University Press.

Hanson, K. (2017). Embracing the past: "Been," "being," and "becoming" children. Childhood, 24(3), 281-285. https://doi. org/10.1177\%2F0907568217715347

Holland, D., Lachicotte, W., Jr., Skinner, D., \& Cain, C. (1998). Identity and agency in cultural worlds. Harvard University Press.

Ingold, T. (2020). The young, the old and the generation of now. Recorded interview, 2nd Riga International Biennial of Contemporary Art "And Suddenly It All Blossoms," August 20-September 13, 2020. https://www.youtube.com/watch?v=UqAbRA8lLIk

James, A., \& Prout, A. (1997). Re-presenting childhood: Time and transition in the study of childhood. In A. James \& A. Prout (Eds.), 
Constructing and reconstructing childhood Contemporary Issues in the sociological study of childhood (pp. 227-246). Falmer Press.

Jenks, C. (1996). Childhood. Routledge.

Kristeva, J. (1981). Women's time (A. Jardine \&H. Blake, Trans.). Signs, 7(1), 13-35. https://www.journals.uchicago.edu/doi/10.1086/493855

Latour, B. (2017). Facing Gaia: Eight lectures on the new climatic regime. Polity Press.

Lee, N. (2001). Childhood and society: Growing up in an age of uncertainty. Open University Press.

Lewis, R. (2014, June 2). How different cultures understand time. Business Insider. https://www.businessinsider.com/how-differentcultures-understand-time-2014-5? $r=$ US\&IR

Maza, S. (2020). The kids aren't all right: Historians and the problem of childhood. The American Historical Review, 125(4), $1261-1285$. https://doi.org/10.1093/ahr/rhaa380

Millei, Z., Silova, I., \& Gannon, S. (2019). Thinking through memories of childhood in (post)socialist spaces: Ordinary lives in extraordinary times. Children's Geographies. https://doi.org/10.1080/14733285.2019.1648759

Miller, J. (2006). Shingwauk's vision: A history of Native residential schools (rev. ed.). University of Toronto Press.

Murris, K., \& Kohan, W. (2020). Troubling troubled school time: Posthuman multiple temporalities. International Journal of Qualitative Studies in Education, 34(7), 581-597. https://doi.org/10.1080/09518398.2020.1771461

Olsen, S. (2014). Juvenile nation: Youth, emotions and the making of the modern British citizen, 1880-1914. Bloomsbury.

Pacini-Ketchabaw, V. (2020). Childhood and temporalities in common world pedagogies. Keynote presentation at Childhood and Time Conference, Tampere, Finland, May 10-12 2021. https://events.tuni.fi/childhood-2020/veronica-pacini-ketchabaw/

Pacini-Ketchabaw, V., \& Kummen, K. (2016). Shifting temporal frames in children's common worlds in the Anthropocene. Contemporary Issues in Early Childhood, 17(4), 431-441. https://doi.org/10.1177\%2F1463949116677930

Rautio, P. (2013). Children who carry stones in their pockets: On autotelic material practices in everyday life. Children's Geographies, 11(4), 394-408. https://doi.org/10.1080/14733285.2013.812278

Rosa, H. (2013). Social acceleration: A new theory of modernity. Columbia University Press.

Rose, N. (1989). Governing the soul: The shaping of the private self. Routledge.

Silova, I., Piattoeva, N., \& Millei, Z. (2017). Childhood and schooling in (post) socialist societies: Memories of everyday life. Palgrave Macmillan.

Spyrou, S. (2020). Editorial: Children as future-makers. Childhood, 27(1), 3-7. https://doi.org/10.1177\%2F0907568219884142

Swain, S., \& Hillel, M. (2010). Child, nation, race, and empire: Child rescue discourse, England, Canada, and Australia, $1850-1915$. Manchester University Press.

Taylor, A., \& Pacini-Ketchabaw, V. (2015). Introduction. In A. Taylor \& V. Pacini-Ketchabaw (Eds.), Unsettling the colonial places and spaces of early childhood education (pp. 1-17). Routledge.

Tesar, M., Farquhar, S., Gibbons, A., Myers, C. Y. \& Bloch, M. N. (2016). Childhoods and time: Rethinking temporality in early childhood education. Contemporary Issues in Early Childhood, 17(4), 359-366. https://doi.org/10.1177\%2F1463949116677931

Truth and Reconciliation Commission of Canada. (2015). Honouring the truth, reconciling for the future: Summary of the final report of the Truth and Reconciliation Commission of Canada. https://publications.gc.ca/site/eng/9.800288/publication.html

Vallgårda, K. (2014). Imperial childhoods and Christian mission: Education and emotions in South India and Denmark. Palgrave Macmillan.

Warming, H. (2020). Childhood prism research: An approach for enabling unique childhood studies contributions within the wider scholarly field. Children's Geographies. https://doi.org/10.1080/14733285.2020.1787952 
Wyness, M. (2006). Childhood and society: An introduction to the sociology of childhood. Palgrave Macmillan. 